\title{
Jurassic dinoflagellate cyst stratigraphy of Store Koldewey, North-East Greenland
}

\author{
Stefan Piasecki, John H. Callomon and Lars Stemmerik
}

\begin{abstract}
The Jurassic of Store Koldewey comprises a Middle Jurassic succession towards the south and an Upper Jurassic succession towards the north. Both successions onlap crystalline basement and coarse sediments dominate. Three main lithostratigraphical units are recognised: the Pelion Formation, including the Spath Plateau Member, the Payer Dal Formation and the Bernbjerg Formation. Rich marine macrofaunas include Boreal ammonites and the successions are dated as Late Bathonian - Early Callovian and Late Oxfordian - Early Kimmeridgian on the basis of new collections combined with material in earlier collections. Fine-grained horizons and units have been analysed for dinoflagellate cysts and the stratigraphy of the diverse and well-preserved flora has been integrated with the Boreal ammonite stratigraphy. The dinoflagellate floras correlate with contemporaneous floras from Milne Land, Jameson Land and Hold with Hope farther to the south in East Greenland, and with Peary Land in North Greenland and Svalbard towards the north. The Middle Jurassic flora shows local variations in East Greenland whereas the Upper Jurassic flora gradually changes northwards in East Greenland. A Boreal flora occurs in Peary Land and Svalbard. The characteristic and stratigraphically important species Perisseiasphaeridium pannosum and Oligosphaeridium patulum have their northernmost occurrence on Store Koldewey, whereas Taeniophora iunctispina and Adnatosphaeridium sp. extend as far north as Peary Land. Assemblages of dinoflagellate cysts are used to characterise significant regional flooding events and extensive sequence stratigraphic units.
\end{abstract}

Keywords: ammonites, Boreal, dinoflagellate cysts, Jurassic, North-East Greenland, Store Koldewey

\footnotetext{
S.P. \& L.S., Geological Survey of Denmark and Greenland, Øster Voldgade 10, DK-1350 Copenhagen K, Denmark. E-mail: sp@geus.dk J.H.C., Department of Chemistry, University College London, 20 Gordon Street, London WC1H OAJ, UK.
}

Jurassic sediments are well exposed in the East Greenland Basin from Milne Land $\left(70^{\circ} \mathrm{N}\right)$ in the south to Hochstetter Forland $\left(75^{\circ} \mathrm{N}\right)$ in the north. Yet farther to the north, Jurassic sediments are restricted to isolated outliers (Ravn 1911; Stemmerik \& Piasecki 1990) until the more extensive outcrops of Jurassic deposits in the Wandel Sea Basin in eastern North Greenland are reached $\left(81^{\circ} \mathrm{N}-83^{\circ} \mathrm{N}\right.$; Fig. 1). The geographical gap between the Jurassic outcrops of the Wandel Sea Ba$\sin$ (Peary Land) and the well-studied ones of the East Greenland Basin corresponds to the zone covering the transition from the strictly Boreal dinoflagellate cyst flora of Peary Land to the Subboreal hybrid flora of
East Greenland. Accordingly, dinoflagellate data from Store Koldewey are important since they improve correlation between these two floral provinces. The Jurassic exposures on the island of Store Koldewey are also stratigraphically important because they provide the nearest accessible record in guiding the evaluation of the hydrocarbon potential of the extensive offshore shelf areas in the northern region.

The Mesozoic of Store Koldewey was first described by Ravn (1911) and Koch (1929) on the basis of data collected by members of 'Danmarks Expeditionen' in 1906-1908. Store Koldewey was then not visited by geologists until the summer of 1989, when several field- 


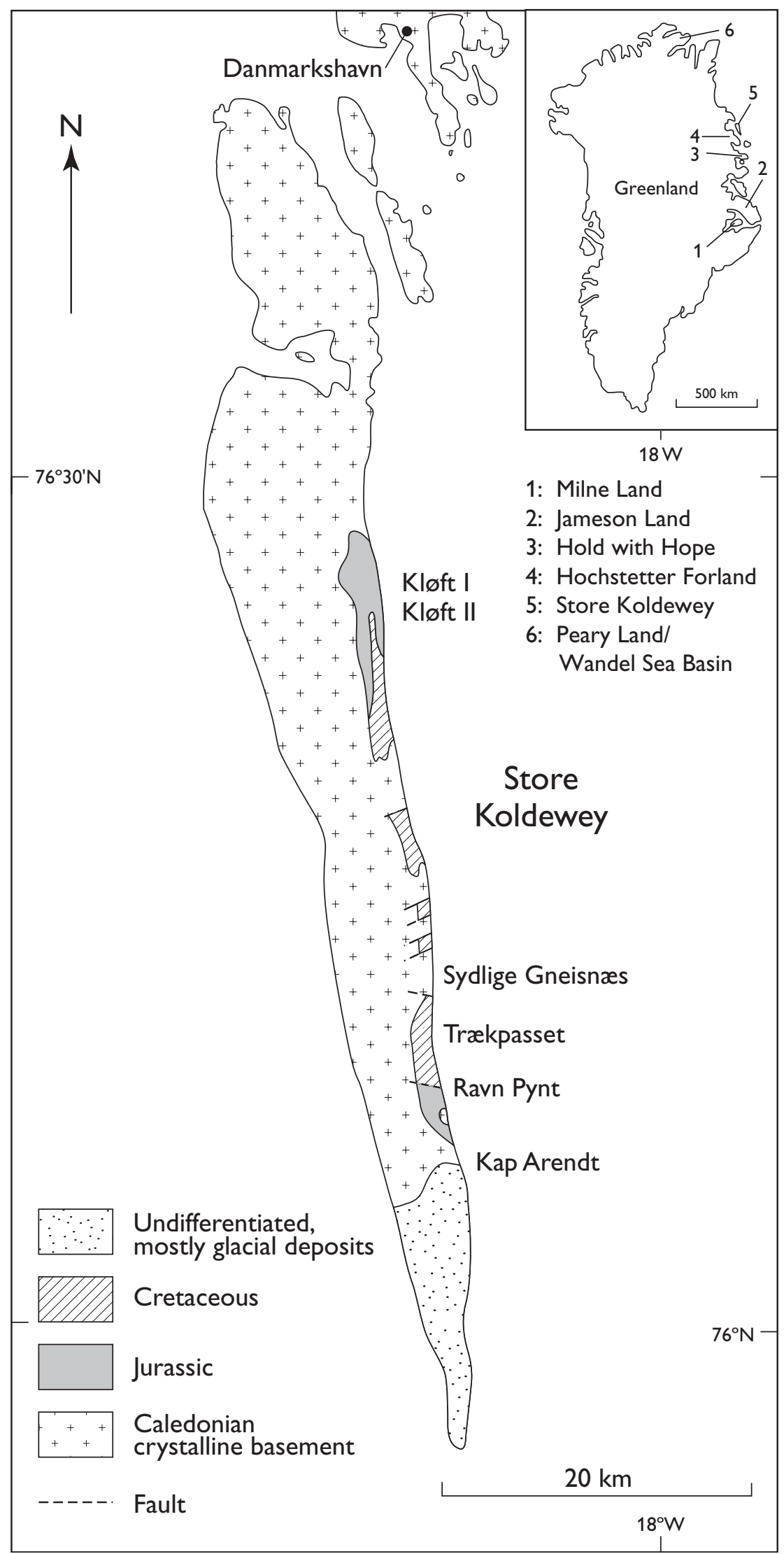

Fig. 1. Simplified geological map of Store Koldewey. 
parties from the Geological Survey of Greenland (GGU; since 1995 part of the Geological Survey of Denmark and Greenland) studied the geology of the island as part of regional mapping projects (Stemmerik \& Piasecki 1990; Henriksen 1997). Other areas mapped as Palaeozoic and Mesozoic sediments by Haller (1983) were also visited at the same time but most of these appeared to be glacial deposits (Stemmerik \& Piasecki 1990). However, some new, very small outcrops of Jurassic sediments were found, protected from erosion on the downthrown side of basement faults (Piasecki et al. 1994).

\section{Geological setting}

The elongated shape of Store Koldewey reflects a north-south-oriented crystalline basement ridge. Mesozoic sediments are exposed only in low coastal cliffs along the east side of the island (Fig. 1). They include four distinct stratigraphic units (I-IV) that are preserved in small structural basins separated by basement highs (Fig. 1). The lithology is generally of mud to fine-grained sand grade and the units are highly fossiliferous. The stratigraphic units are of Middle Jurassic (I), Late Jurassic (II) and Early Cretaceous ages (III-IV). The southernmost outcrop at Ravn Pynt consists of a Middle Jurassic succession more than $60 \mathrm{~m}$ thick, the Trækpasset Formation (Koch 1929; Figs 1, 2). Upper Jurassic sediments crop out in two gullies, Kløft I and Kløft II, in the northern part of the island (Fig. 1). The sediments in the first (northern) af these gullies have been referred to the Kløft I Formation (Koch 1929) based on the description by Ravn (1911) of material collected by members of the 'Danmarks Ekspeditionen' in 1906-1908. Ravn (1911) proposed a Callovian age for the Trækpasset Formation and a 'Sequanian' (Kimmeridgian) age for the Kløft I Formation based on ammonites. The sandstone of the Kløft I Formation was later found in the Kløft II locality to be overlain with a sharp boundary by grey laminated mudstones of the Bernbjerg Formation (Piasecki et al. 1994).

\section{Samples and methods}

The palynological samples were prepared by standard preparation methods including treatment with hydrochloric and hydrofluoric acids, oxidation and filtration with 20 micron mesh. The stratigraphical position of the Middle Jurassic samples is marked on the sedi- mentological log from Ravn Pynt (Fig. 2). This succession is well dated by ammonites and the recorded occurrences and distributions of dinoflagellate cysts are mainly used to improve the precision of Middle Jurassic dinoflagellate cyst stratigraphy in East Greenland. This has involved new palynological analyses of ammonite-dated samples from Jameson Land for confirmation of the new stratigraphical results from Store Koldewey. These new data are not published yet, but are referred to in this paper. The new ammonite records are not yet published in detail but are utilised in this paper.

The position of the Upper Jurassic samples is marked on the sedimentological log from Kløft II (see Fig. 5). The record of dinoflagellate cysts is then used to date the regionally recorded transition from shallow marine sandstone to the shale of the Bernbjerg Formation. The dinoflagellate assemblages are correlated with older ammonite data, but the samples were not themselves directly associated with ammonites. A number of new species have been described and defined separately (Piasecki 2001).

\section{Middle Jurassic}

\section{Lithostratigraphy}

The Middle Jurassic succession on Store Koldewey, the Trækpasset Formation of Koch (1929), is a lateral equivalent in part of the geographically widespread Pelion Formation, and as there is little reason to maintain a separate stratigraphy for Store Koldewey, it is herewith re-assigned to the Pelion Formation. The upper part of the exposed succession is of Early to Middle Callovian age and biostratigraphically equivalent to the new Spath Plateau Member on Hold with Hope (Vosgerau et al. 2004, this volume) where the same two ammonite zones are recorded. This part of the Store Koldewey succession provides dinoflagellate cyst data from an interval that is not so well documented in Jameson Land (Milner \& Piasecki 1996).

Ammonites and dinoflagellate cysts in the succession at Ravn Pynt may indicate a depositional break between the Bathonian and the Callovian parts of the Pelion Formation (Figs 3, 4). The basal Callovian comprises the only significant mudstone in this succession. This shift in depositional facies is associated with the appearance of Callovian ammonites and several of the uppermost Bathonian ammonite zones are not recorded beneath the facies shift. The absence of these zones 


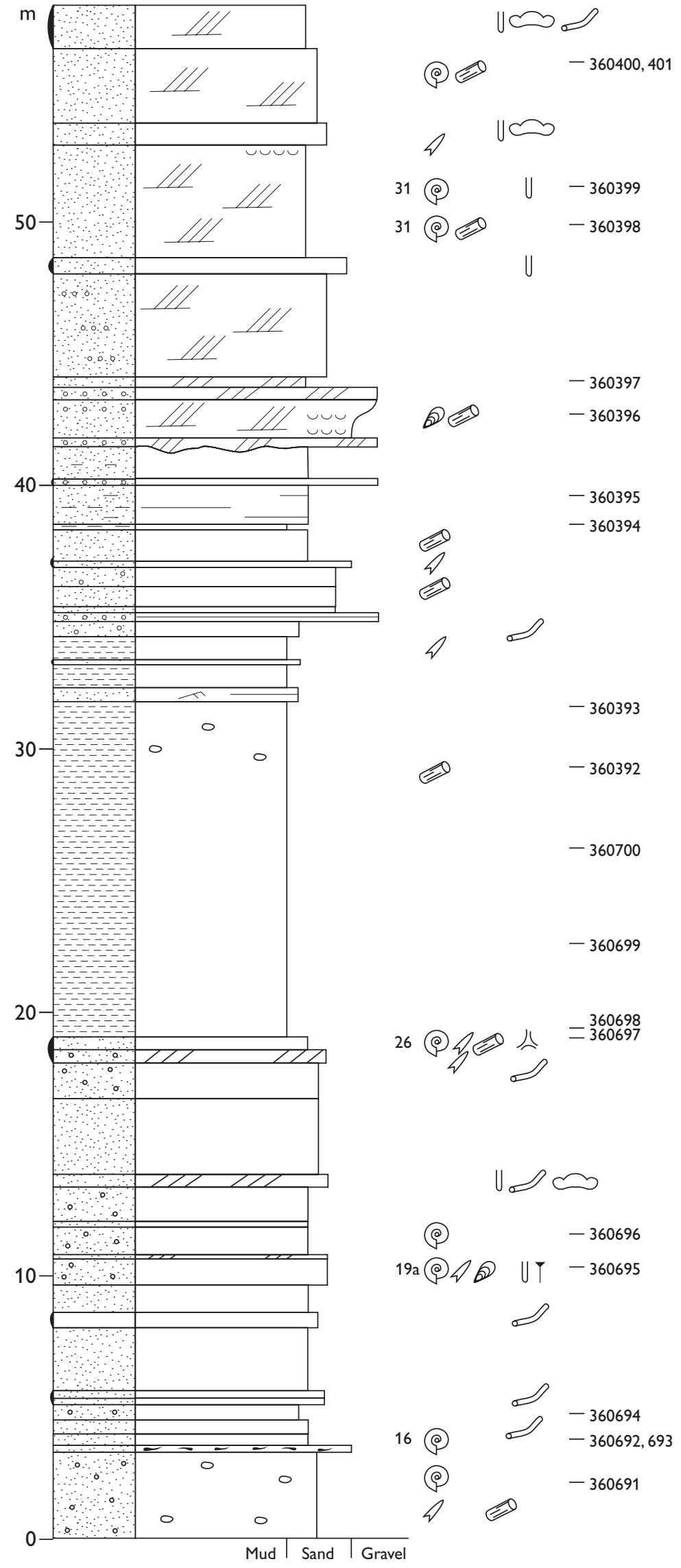

\section{Lithology \\ Sand \\ Sand with gravel \\ Mud}

\section{Structure}

\begin{tabular}{|c|c|}
\hline & Lamination \\
\hline & Lenticular lamination \\
\hline & Planar cross-bedding \\
\hline & Shell bed \\
\hline & Clay clasts \\
\hline & Calcareous concretions \\
\hline & Hardened bed \\
\hline
\end{tabular}

Fossils

八 Thalassinoides isp.

$\curvearrowleft$ Curvolithos isp.

Y Monocraterion isp.

U Diplocraterion isp.

2 Planolites isp.

16 () Boreal ammonite fauna horizon

4 Belemnite

(1) Bivalve

(1) Pinna sp.

$\Leftrightarrow$ Wood

D Serpulid

एय Oyster

360691 GGU sample numbers
Fig. 2. Sedimentological log of the exposed Middle Jurassic succession at Ravn Pynt. Levels of the analysed palynological samples are indicated. 
may indicate a hiatus in the sedimentary succession or simply no preservation of fauna and flora in that specific part of the section. Some of the absent ammonite faunas, however, have been collected just south of Ravn Pynt on Store Koldeway.

\section{Ammonites}

The Jurassic succession contains abundant ammonites in well-separated faunal horizons and the stratification is generally preserved despite some solifluction. The sedimentological succession was studied in a ravine at Ravn Pynt and four ammonite horizons were collected here in situ and directly correlated with the fine-grained palynological samples (Fig. 2). These ammonites represent the Arcticoceras ishmae Zone (horizon 16), the Arcticoceras cranocephaloide Zone (horizon 19a including topotypes of Kepplerites tychonis Ravn), the Cadoceras apertum Zone (horizon 26) and the Proplanulites koenigi Zone (horizon 31) of the standard Boreal ammonite biostratigraphy of Jameson Land (Callomon 1993). The age of the succession is then midBathonian to Callovian based on the ammonite faunas.

\section{Dinoflagellate cysts}

The organic matter in the Middle Jurassic succession is dominated by black and brown woody material. The abundance of dinoflagellate cysts is generally low but the diversity is fair ( 65 recorded species, including a few acritarchs). The assemblages are dominated by proximate cysts accompanied by few cavate cysts but are basically barren of chorate cysts. Specimens from the Pareodinia/Paraevansia/Evansia and the Escharisphaeridium/Sentusidinium groups are the most abundant cysts. Successive species appear regularly upwards in the succession but the highest number of appearances is in GGU sample 360698 at $19.60 \mathrm{~m}$ (Fig. 4) at the base of a $13 \mathrm{~m}$ thick fine-grained interval (Fig. 2). This may reflect a hiatus in the succession below the sample and/or a shift to a more open marine depositional environment.

Since the Middle Jurassic succession is dated in detail by ammonites, the distribution of the dinoflagellate cysts can be used to increase the precision of their ranges in the Boreal Jurassic as previous recorded in other regions in East Greenland (Jameson Land and Hold with Hope). Sirmiodinium grossii, Gonyaulacysta pectinigera, Paragonyaulacysta retiphragmata and
Chytroeisphaeridia byalina are the stratigraphically important species that occur throughout the investigated succession. S. grossii appears in the Arctocephalites arcticus Chronozone in Milne Land (Larsen et al. 2003) and becomes more frequent from approximately the Arctocephalites cranocephaloide Chronozone and upwards to the Cadoceras apertum Chronozone (Milner \& Piasecki 1996). This increase in abundance of $S$. grossii is not observed here because no samples were collected from this part of the section. In Milne Land, G. pectinigera is recorded as becoming abundant from the $A$. cranocephaloide Chronozone upwards into the C. apertum Chronozone but again, this increase in abundance is not represented in the present section. In Jameson Land, P. retiphragmata has its earliest appearance in the $A$. cranocephaloide Chronozone but at Store Koldewey it clearly appears already in the Arcticoceras ishmae Chronozone. C. byalina appeared earliest in the Cadoceras calyx Chronozone in Jameson Land (Milner \& Piasecki 1996). The present material, in combination with new data from Jameson Land, show that $C$. byalina is present already in the $A$. ishmae Chronozone and becomes abundant from the $C$. apertum Zone. Aldorfia aldorfensis appears in the $A$. cranocephaloide Chronozone precisely where it is expected from its range in Jameson Land (Milner \& Piasecki 1996). The morphologically variable species Ctenidodinium thulium is recorded throughout the succession, having a much more extensive range than that recorded elsewhere in East Greenland. Towards the south, in Milne Land, it is restricted to the interval above the $A$. cranocephaloide Chronozone and below the Paltoceras atbleta Chronozone (Larsen et al. 2003). This upper range is confirmed in these northern regions by data from Hold with Hope where it is recorded in strata just below the P. atbleta Chronozone (Piasecki et al. 2004, this volume).

Many of the less frequent species seem to occur in a rather random way that makes their presence and especially their absence less stratigraphically useful. Crussolia perireticulata is a good example of this. In Milne Land, it occurs in the Bathonian A. arcticus Chronozone and again higher in the Callovian part of the succession (Larsen et al. 2003). In Jameson Land, it appears one ammonite zone higher than in Milne Land, the Bathonian Arctocephalites greenlandicus Chronozone and is then not recorded again until it reappears in the basal Callovian, top C. apertum Chronozone. There are no records of this species from the Bathonian or the Callovian of Store Koldewey and Hold with Hope. This could indicate a southern affinity of this 


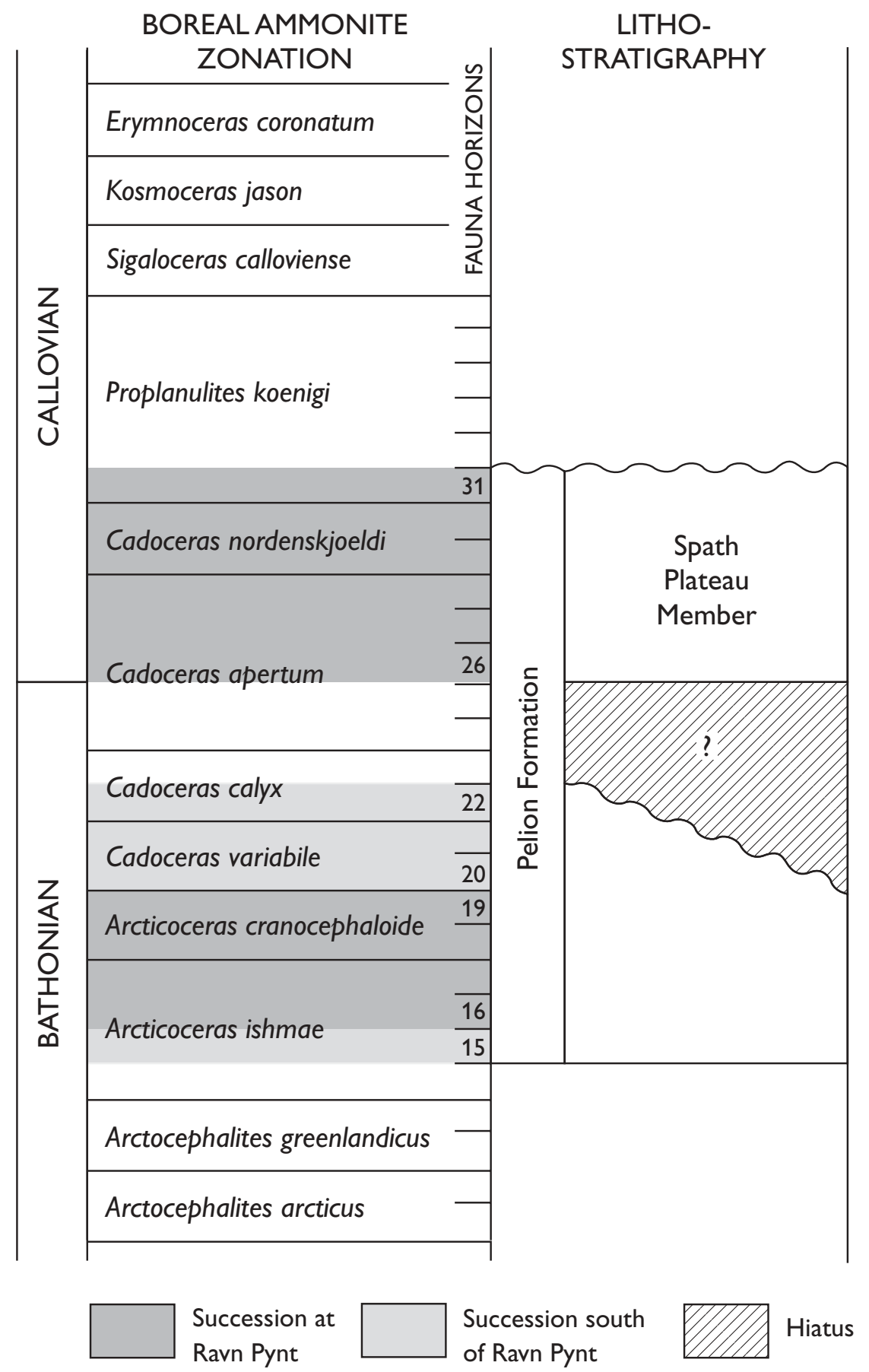

Fig. 3. Schematic stratigraphical classification of the Middle Jurassic succession on Store Koldewey.

species as the depositional settings of these localities are comparable overall. However, a Callovian range is reported from the present Arctic regions of the Sverdrup Basin and Svalbard (Smelror 1993).

Some exceptionally early occurrences of Ambonosphaera calloviana and Gonyaulacysta helicoidea in the A. ishmae Chronozone and of Pareodinia stegasta and Paraevansia brachythelis in the C. apertum Chronozone are recorded in the present succession.
The dinoflagellate cysts in the Middle Jurassic succession are divided into an Upper Bathonian and a Lower Callovian dinoflagellate cyst assemblage. The boundary is placed at $19.2 \mathrm{~m}$, above which level a significant number of new species appear (Figs 2, 4). Most species in the Upper Bathonian assemblage also occur in the Lower Callovian assemblage and the composition of the Bathonian assemblage varies significantly between the few samples studied. The younger, 


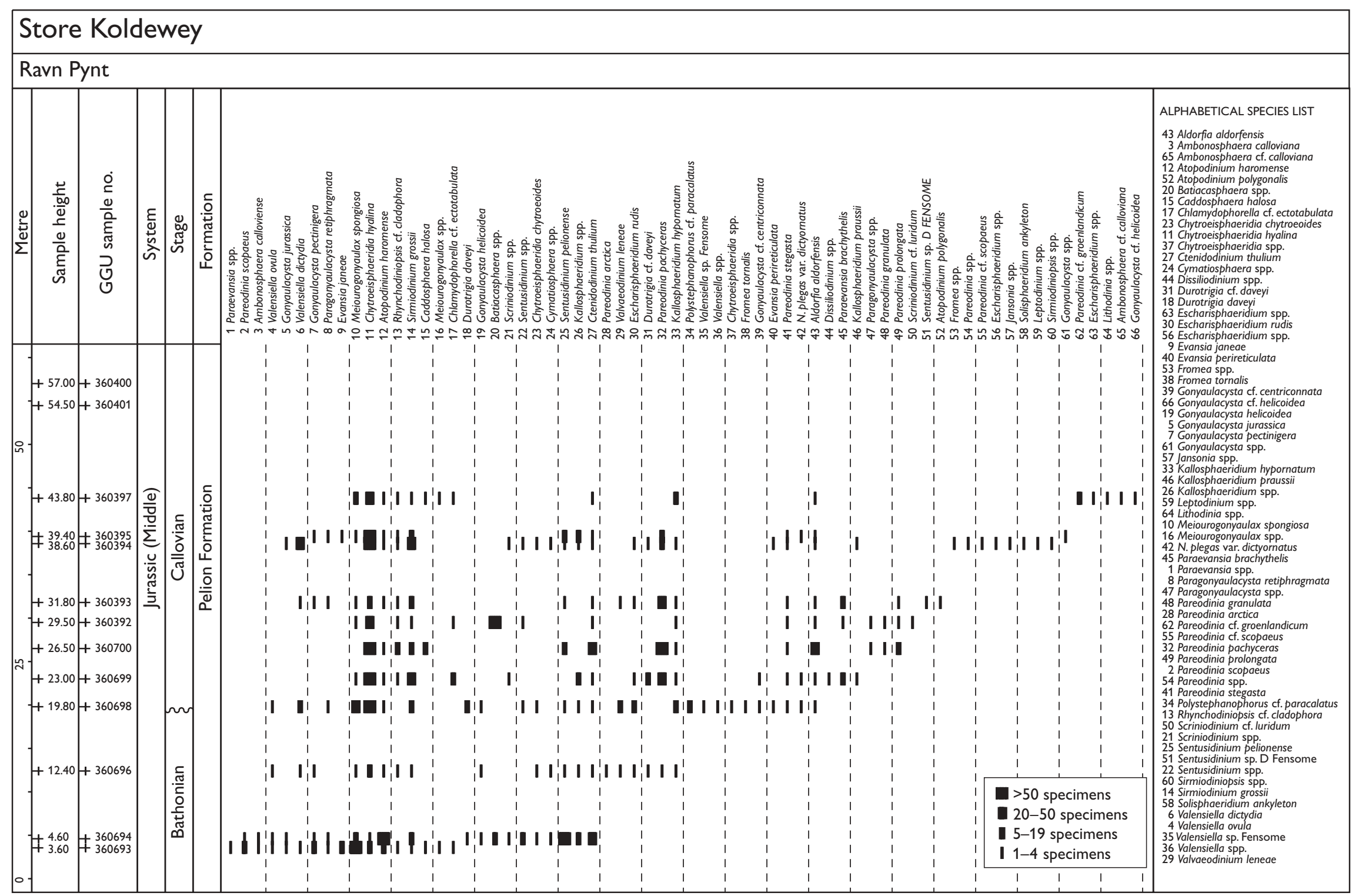

Fig. 4. Distribution chart of the dinoflagellate cysts in the Middle Jurassic succession at Ravn Pynt on Store Koldewey. 
Lower Callovian assemblage is characterised by abundant Chytroeisphaeridia byalina and Pareodinia pachyceras, together with many species not present below e.g. Pareodinia stegasta, Aldorfia aldorfiense and Paraevansia brachythelis.

\section{Middle Jurassic correlation}

The dinoflagellate cyst assemblage of the lower part of the succession (Bathonian) correlates with assemblages of the A. arcticus - A. cranocephaloide Chronozones from both Milne Land (Assemblages 2 and 3 in: Larsen et al. 2003) and Jameson Land (Milner \& Piasecki 1996) in central East Greenland. The assemblages from the Charcot Bugt Formation in Milne Land are very poor, both in diversity and density, but have stratigraphically significant species such as S. grossii, C. byalina, Kallosphaeridium hypornatum and Evansia janeae in common with the present assemblage. In the same stratigraphical interval in the Fossilbjerget Formation of Jameson Land, new species appear for the first time in abundance and have many species in common with the assemblage from Store Koldewey. Differences in occurrence and first appearances of significant species between the two areas are discussed above.

The dinoflagellate cyst assemblage of the higher part of the succession (Lower Callovian) on Store Koldewey also correlates well with assemblages from the Charcot Bugt Formation in Milne Land, whereas the contemporaneous assemblages from the Fossilbjerget Formation in Jameson Land are poor and not so well documented. In contrast, dinoflagellate cyst assemblages from the Pelion Formation, Spath Plateau Member, on Hold with Hope (Piasecki et al. 2004, this volume) correlate well with assemblages from Store Koldewey. The assemblages in the Charcot Bugt Formation (Assemblages 4 and 5 in: Larsen et al. 2003) are not precisely dated but are not older than the $A$. cranocephaloide Chronozone (Bathonian) and not younger than the Erymnoceras coronatum Chronozone (top Middle Callovian).

\section{Discussion}

The correlation of the Pelion Formation on Store Koldewey with the Charcot Bugt, the Fossilbjerget and the Pelion Formations in southern parts of the Jurassic East Greenland basin complex shows that time-equivalent sedimentary successions exist regionally in different lithostratigraphical units. The Middle Jurassic dinoflagellate assemblages vary with depositional environments but the overall characters can be recognised and correlated over long distances.

The main problem is the interdependence of deposition of relatively fine-grained sediments and preservation of dinoflagellate cysts, giving relatively few horizons with rich assemblages in the generally coarsegrained Middle Jurassic successions, i.e. the Pelion and Charcot Bugt Formations.

\section{Upper Jurassic}

\section{Lithostratigraphy}

The Upper Jurassic succession on Store Koldewey was defined as the Kløft I Formation (Koch 1929). Its lower sandstone-dominated part is equivalent to the recently defined Payer Dal Formation (Alsgaard et al. 2003) from Hold with Hope, Kuhn $\varnothing$ and Hochstetter Forland further to the south, and the overlying mudstones are equivalent to the geographically extensive Bernbjerg Formation (Fig. 5). For convenience and simplification of the lithostratigraphy, the Kløft I Formation is not used here and the succession is referred to the Payer Dal and Bernbjerg Formations (Fig. 5).

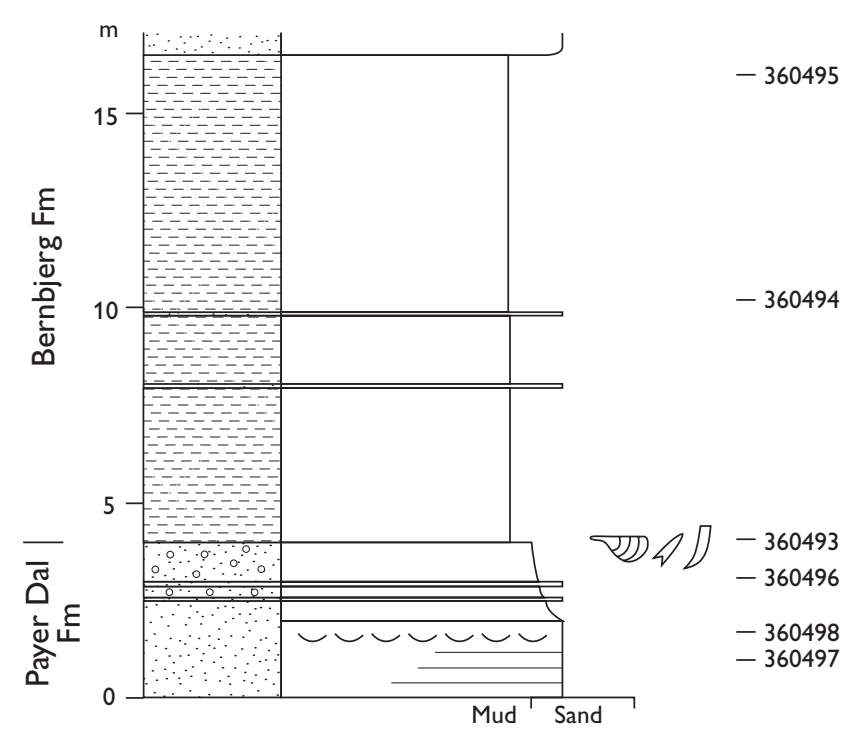

Fig. 5. Sedimentological log of the exposed Upper Jurassic succession at Kløft II with the levels of analysed samples marked. For legend, see Fig. 2. 
Fig. 6. Schematic stratigraphical classification of the Upper Jurassic succession on Store Koldewey.

\begin{tabular}{|c|c|c|}
\hline & $\begin{array}{c}\text { Chronostratigraphy } \\
\text { Chronozones }\end{array}$ & $\begin{array}{c}\text { Lithostratigraphy } \\
\text { Formations }\end{array}$ \\
\hline \multirow{3}{*}{ 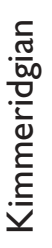 } & Aulacostephanoides mutabilis & Bernbjerg \\
\hline & Rasenia cymodoce & \multirow{5}{*}{ Payer Dal } \\
\hline & Pictonia baylei & \\
\hline \multirow{5}{*}{$\begin{array}{l}\frac{\bar{\sigma}}{0} \\
\frac{0}{0} \\
\frac{0}{x} \\
0\end{array}$} & Amoeboceras rosenkrantzi & \\
\hline & Amoeboceras regulare & \\
\hline & Amoeboceras serratum & \\
\hline & Amoeboceras glosense & \multirow[b]{2}{*}{$\begin{array}{l}\text { Based on } \\
\text { dinoflagellate cysts }\end{array}$} \\
\hline & $\begin{array}{l}\text { Based on } \\
\text { ammonites }\end{array}$ & \\
\hline
\end{tabular}

\section{Ammonites}

The old ammonite collections from the Kløft I Formation (Payer Dal Formation) described by Ravn (1911) were recently correlated more precisely with the British ammonite succession, confirming a Late Oxfordian to Early Kimmeridgian age, equivalent to the Amoeboceras serratum, A. rosenkrantzi and Aulacostephanoides mutabilis Zones (Fig. 6; Sykes \& Surlyk 1976; Sykes \& Callomon 1979). New ammonite finds indicate a similar age. These ammonites are not precisely located but most probably came from the sandstones referred here to the Payer Dal Formation. The samples analysed for dinoflagellate cysts are from the top of this formation and from the overlying Bernbjerg Formation (Fig. 6).

\section{Dinoflagellate cysts}

The organic content of the Upper Jurassic samples is dominated by brown and black woody material and the abundance and diversity of the dinoflagellate cyst floras are low. The richest samples are from the base of the Bernbjerg Formation, probably representing a flooding event. The dinoflagellate cysts are better preserved in the Payer Dal Formation than in the Bernbjerg Formation. The composition of the dinoflagellate cyst flora is clearly in favour of proximate cysts, with a minority of chorate specimens and species.
The Upper Jurassic succession comprises two assemblages, which intermingle at the transition from Payer Dal to Bernbjerg Formation (Fig. 7). The lower assemblage is characterised by Gonyaulacysta dualis, Adnatosphaeridium sp. (A. hartzi in: Piasecki 1980), Taeniophora iunctispina, Ambonosphaera calloviana and Paragonyaulacysta capillosa. This assemblage is well known from Oxfordian/Kimmeridgian strata in Milne Land in East Greenland (Piasecki 1980; Piasecki 1996), Hochstetter Forland (Piasecki \& Stemmerik 2004, this volume) and in Peary Land, North Greenland (Håkansson et al. 1981; Piasecki 1994).

The upper assemblage is characterised by Paragonyaulacysta capillosa, Occisucysta sp., Perisseiasphaeridium pannosum, Rhynchodiniopsis sp. and Rhynchodiniopsis cf. pennata. This assemblage is known from Kimmeridgian strata in Milne Land with a slightly different frequency of the species involved (Piasecki 1996), and from Peary Land, North Greenland (Piasecki 1994) and Svalbard (Århus 1988).

The earliest Paragonyaulacysta capillosa on Milne Land appears in the basal Kimmeridgian, Rasenia cymodoce Chronozone, shortly before the earliest Perisseiasphaeridium pannosum and Avellodinium cf. falsificum at the base of the A. mutabilis Chronozone. These two events are recorded within an assemblage of abundant Adnatosphaeridium sp. (A. hartzi in: Piasecki 1980), Taeniophora iunctispina, Gonyaulacysta jurassica/dualis and Ambonosphaera calloviana that dominates from the Late Oxfordian (A. rosenkrantzi 


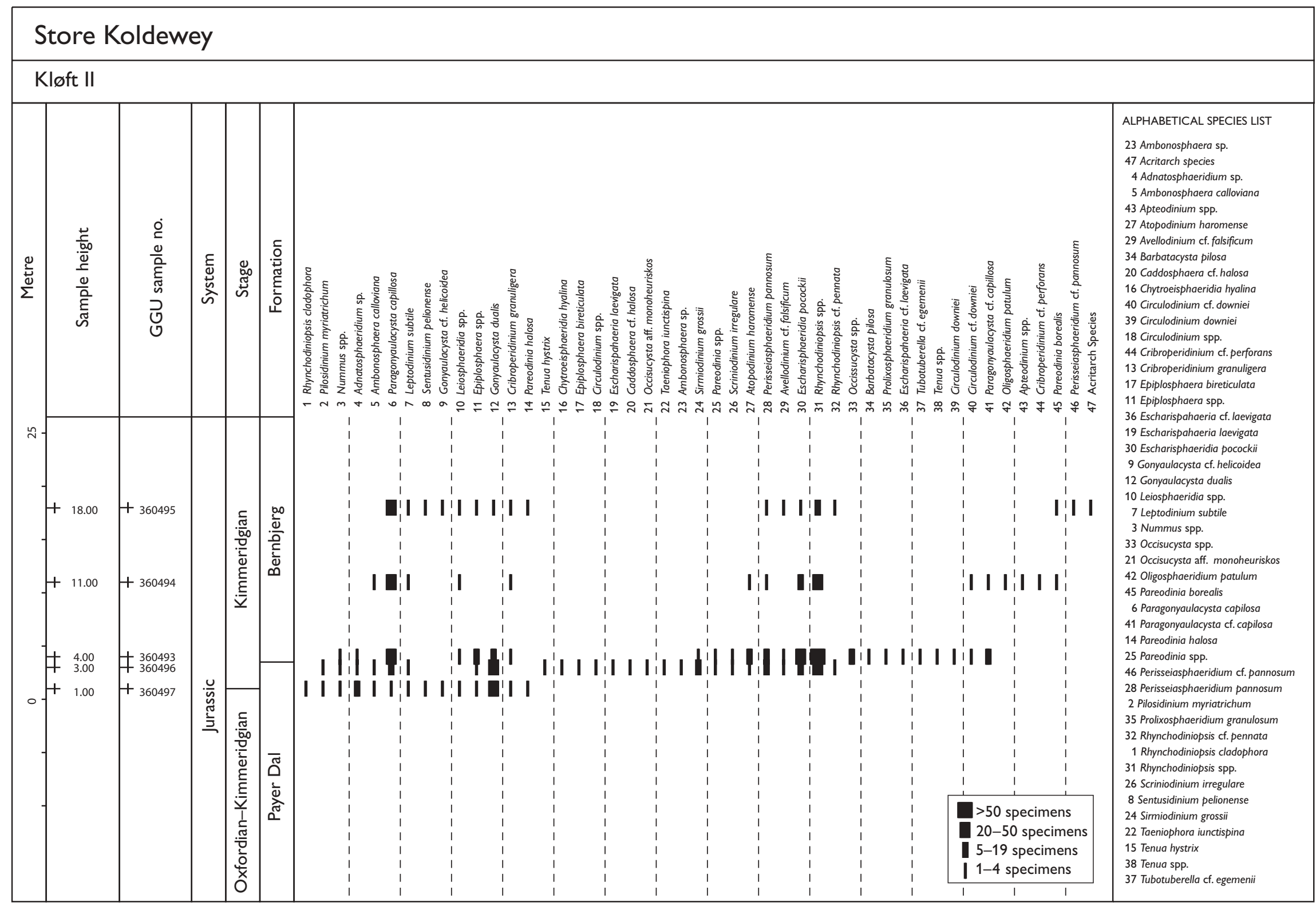

Fig. 7. Distribution chart of the dinoflagellate cysts in the Upper Jurassic succession at Kløft II on Store Koldewey. 
Chronozone) to the earliest Kimmeridgian (Pictonia baylei and R. cymodoce Chronozones). A similar order of appearances occurs in the Upper Jurassic succession of Store Koldewey and the presence of Occisucysta sp. in these strata also supports a stratigraphical level equivalent to the R. cymodoce Chronozone by comparison with the assemblages from Milne Land.

$P$. pannosum becomes abundant in Milne Land in the $A$. mutabilis Chronozone and dominates the dinoflagellate assemblages throughout the A. eudoxus Zone until Oligosphaeridium patulum becomes the totally dominant species in the A. autissiodorensis Chronozone. The assemblage on Store Koldewey contains Perisseiasphaeridium pannosum most abundantly at the transition between the two formations and Oligosphaeridium patulum follows rapidly at the base of Bernbjerg Formation. None of the two species are abundant at higher levels in the Bernbjerg Formation at Kløft II.

\section{Upper Jurassic correlation}

The Upper Jurassic dinoflagellate cyst assemblages on Store Koldewey closely resemble the Boreal assemblages from the Jurassic Ladegårdsåen Formation of Peary Land (Piasecki 1994), and to some degree also the assemblage in the Janusfjellet Formation, Svalbard (Århus 1988). However, the restricted ammonite faunas in these two formations do not allow precise dating of the dinoflagellate assemblages on Peary Land and Svalbard. The most significant difference between these assemblages is the presence of P. pannosum and O. patulum only at Store Koldewey. Adnatosphaeridium sp. and Taeniophora iunctispina occur as far north as Peary Land but are not reported from Svalbard.

The stratigraphically highest occurrence of Gonyaulacysta dualis, Atopodinium haromense, Occisucysta sp. in Peary Land, in an assemblage with abundant Escharisphaeridium pocockii, Rbynchodiniopsis sp., Taeniophora iunctispina and Adnatosphaeridium sp. is associated with the appearance of Paragonyaulacysta capillosa and Cribroperidinium perforans. This assemblage and associated stratigraphic events in Peary Land are directly comparable with the dinoflagellate cyst assemblage at the transition from the Payer Dal Formation to the Bernbjerg Formation on Store Koldewey. The age of this assemblage is interpreted to be Early Kimmeridgian (R. cymodoce-A. mutabilis Chronozones).

A comparable event has not been recorded in the
Kimmeridgian of Svalbard (Janusfjellet Formation) where only Paragonyaulacysta capillosa seems to have stratigraphical potential, with a consistently relative short range (Århus 1988). There, P. capillosa appears after a poor to barren interval in the Upper Oxfordian to lowermost Kimmeridgian, above a poor ammonite record of Rasenia sp. and at a level where bioturbated mudstones are followed by laminated mudstones, just as on Store Koldewey and in Milne Land. The appearance of $P$. capillos $a$ and its associated assemblage may therefore reflect a relative sea-level rise. The presence of $P$. capillosa and its associated dinoflagellate cyst assemblage may be used as a general indication of the stratigraphical level from the $R$. cymodoce Chronozone into the $A$. mutabilis (A. eudoxus?) Chronozone. The few other associated species in the Janusfjellet section are the stratigraphically long-ranging species Paragonyaulacysta borealis, Lanterna saturnalis and Tubotuberella apatela, the typical Borealis Assemblage (Brideaux \& Fisher 1976) which also occurs in East and North Greenland.

The dinoflagellate cyst assemblages in Peary Land and Svalbard provide no clear upper stratigraphical limits, except for the disappearance of P. capillosa. $P$. capillosa occurs commonly up to the A. autissiodorensis Chronozone (top Kimmeridgian) in Milne Land but is also recorded scattered throughout the Volgian. The successions at Store Koldewey, Peary Land and Svalbard within the range of abundant P. capillosa are therefore considered to be of Kimmeridgian (pre-Volgian) age.

\section{Discussion}

Despite the similarity in composition and abundance of specific species in the geographically widespread assemblages described above, there are also clear differences reflecting the latitudinal distance between the compared localities. The Upper Jurassic dinoflagellate cyst assemblage on Store Koldewey is a mixture of species with Subboreal or Boreal preference but with a clear affinity to the Boreal region. P. pannosum and O. patulum are abundant and long-ranging in Northwest Europe, they are abundant with a more restricted stratigraphical range in East Greenland, and they appear in low numbers with a limited stratigraphical range in Store Koldewey. This is probably close to the northern limit of these species as they do not appear farther to the north in Peary Land (Piasecki 1994) and Svalbard (Århus 1988). On Store Koldewey, the occurrence of these species so far north is associated with the most 
significant relative sea-level rise recorded in the Upper Jurassic of East Greenland, in the $R$. cymodoce to A. mutabilis (A. eudoxus) Chronozones of the Kimmeridgian.

\section{Sequence stratigraphic implications}

Studies of the Jurassic ammonite and dinoflagellate cyst stratigraphy integrated with sedimentological studies and sequence stratigraphical interpretations in East Greenland lead towards an integrated genetic model in which the units can be identified by their content of dinoflagellate cysts. The present study of the dinoflagellate cyst assemblages on Store Koldewey contributes to the study of this complex problem.

The Middle Jurassic succession deposited directly on crystalline basement on Store Koldewey correlates with contemporaneous and stratigraphically similar successions from the lower part of the Fossilbjerget Formation in Jameson Land (P5 and P6 third-order sequences of Engkilde \& Surlyk 2003), the Charcot Bugt Formation in Milne Land (Larsen et al. 2003) and the Pelion Formation at Hold with Hope (Vosgerau et al. 2004, this volume). Both in Milne Land and on Hold with Hope, the Middle Jurassic successions represent the earliest evidence of the Jurassic transgression of the margins of the sedimentary basins. The ammonite fauna from the $A$. ishmae Chronozone is among the most widespread faunas in the Arctic (Callomon 1993) and marks the considerable extent of this circum-Arctic second-order marine transgression represented also in most areas of East Greenland. The third-order depositional sequence P5 in Jameson Land is limited by sequence boundaries located in the $A$. ishmae and $C$. calyx Chronozones, respectively (Engkilde \& Surlyk 2003). The P6 depositional sequence is confined to the C. apertum, C. nordenskjoeldi and basal P. koenigi Chronozones. Stratigraphically, P5 and P6 correspond to the two sedimentological units identified in the Middle Jurassic of Store Koldewey and their content of dinoflagellate cysts correlates as well.

In Milne Land, the Charcot Bugt Formation also contains ammonites from the $A$. ishmae and the A. cranocephaloide Zones (Larsen et al. 2003). The associated dinoflagellate cyst assemblages correlate well with assemblages from the corresponding lower Pelion succession on Store Koldewey. Dinoflagellate cysts from the higher Pelion Formation, the Spath Plateau Member, at Store Koldewey ( $C$. apertum Chronozone to the basal P. koenigi Chronozone) correlate with those from Assemblage 4 from the Charcot Bugt Formation.

On Hold with Hope, the Pelion Formation comprises two sedimentological units: a lower sandstone unit followed by the Spath Plateau Member (Vosgerau et al. 2004, this volume). Ammonites indicating the $C$. apertum Zone and the P. koenigi Zone occur in the basal strata of Spath Plateau Member. Dinoflagellate cyst assemblages equivalent to the assemblages from the corresponding Spath Plateau Member on Store Koldewey have been recorded in this succession (Piasecki et al. 2004, this volume).

Thus, two distinct dinoflagellate cyst assemblages of Bathonian and Callovian age characterise the two sedimentological units that have been identified as third-order depositional sequences and are found to be extensively distributed throughout East Greenland.

As already mentioned above, the Upper Jurassic succession on Store Koldewey, consisting of the Payer Dal and Bernbjerg Formations, correlates excellently with contemporaneous successions from eastern Peary Land and Svalbard in the north to Milne Land in the south. The overall transgressive trend from the Upper Oxfordian to maximum flooding in the Kimmeridgian is represented by sedimentary deposits throughout East and North Greenland that can be correlated in detail on the basis of both ammonites and dinoflagellate cysts. A succession of distinct dinoflagellate cyst assemblages characterises the stepwise progress of relative sea-level rise and can be recognised throughout the sedimentary basins of East Greenland.

\section{Conclusion}

The Jurassic succession of Store Koldewey is divided into the Pelion, Payer Dal and Bernbjerg Formations. Abundant Boreal ammonites date the succession in detail and associated floras of dinoflagellate cyst provide supplementary data. The Pelion Formation is dated as Late Bathonian - Early Callovian, in the Middle Jurassic, and the Payer Dal and Bernbjerg Formations are dated as Late Oxfordian - Early Kimmeridgian in the Late Jurassic.

The Middle Jurassic succession consists of a Bathonian and a Callovian part. They can be correlated with contemporaneous sedimentary successions on Hold with Hope, in Jameson Land and in Milne Land to the south, where corresponding dinoflagellate cyst assemblages have been recorded. Ranges of individual dinoflagellate species are given in relation to the Boreal ammonite stratigraphy. 
The Upper Jurassic succession is correlated with corresponding successions in Hochstetter Forland, Hold with Hope and Milne Land to the south and with those of Peary Land, North Greenland, and Svalbard to the north. Passing northwards from East Greenland via North Greenland to Svalbard, the Upper Jurassic dinoflagellate cyst floras show a transition from dominantly Subboreal species in central East Greenland to a distinct Boreal flora in Svalbard. The stratigraphic ranges of many species and their abundance decrease towards the north. In contrast, species with Boreal affinity range southwards to Milne Land. The assemblages in Store Koldewey are transitional in composition.

The sedimentological units of Store Koldewey are placed in the sequence stratigraphic framework developed for the Jurassic in East Greenland, and the associated dinoflagellate cyst assemblages are used to characterise and to identify these sequence stratigraphic elements.

\section{Acknowledgements}

Work began as part of the Project 'Resources of the sedimentary basins of North and East Greenland', supported by the Danish Research Councils. The work was completed with support from the Carlsberg Foundation (Carlsbergfondet) Ans. 980089/20-262. The authors are grateful to Dr. A. Wierzbowski and Dr. G.F.W. Herngreen for careful comments and constructive suggestions.

\section{References}

Alsgaard, P.C., Felt, V.L., Vosgerau, H. \& Surlyk, F. 2003: The Jurassic of Kuhn $\varnothing$, North-East Greenland. In: Ineson, J.R. \& Surlyk, F. (eds): The Jurassic of Denmark and Greenland. Geological Survey of Denmark and Greenland Bulletin 1, 865-892.

Århus, N. 1988: Palynostratigraphy of some Bathonian-Hauterivian sections in the Arctic, with emphasis on the Janusfjellet Formation type section, Spitsbergen. Institutt for Kontinentalsokkelundersøkelser (IKU) Report 23.1252.11/01/88, 139 pp.

Brideaux, W.W. \& Fisher, M.J. 1976: Upper Jurassic - Lower Cretaceous dinoflagellate assemblages from Arctic Canada. Geological Survey of Canada Bulletin 259, 1-53.

Callomon, J.H. 1993: The ammonite succession in the Middle Jurassic of East Greenland. Bulletin of the Geological Society of Denmark 40, 83-113.

Engkilde, M. \& Surlyk, F. 2003: Shallow marine syn-rift sedimentation: Middle Jurassic Pelion Formation, Jameson Land,
East Greenland. In: Ineson, J.R. \& Surlyk, F. (eds): The Jurassic of Denmark and Greenland. Geological Survey of Denmark and Greenland Bulletin 1, 813-863.

Håkansson, E., Birkelund, T., Piasecki, S. \& Zakharov, V. 1981: Jurassic-Cretaceous of the extreme Arctic (Peary Land, North Greenland). Bulletin of the Geological Society of Denmark 30, 11-42.

Haller, J. 1983: Geological map of Northeast Greenland $75^{\circ}-$ $82^{\circ} \mathrm{N}$ Lat. Meddelelser om Grønland 200(5), 22 pp.

Henriksen, N. 1997: Geological map of Greenland 1:500 000, Sheet 10, Dove Bugt. Copenhagen: Geological Survey of Denmark and Greenland.

Koch, L. 1929: Stratigraphy of Greenland, 124 pp. Dr. Scient thesis, University of Copenhagen, Denmark.

Larsen, M., Piasecki, S. \& Surlyk, F. 2003: Stratigraphy and sedimentology of a basement-onlapping shallow marine sandstone succession, the Charcot Bugt Formation, Middle-Upper Jurassic, East Greenland. In: Ineson, J.R. \& Surlyk, F. (eds): The Jurassic of Denmark and Greenland. Geological Survey of Denmark and Greenland Bulletin 1, 893-930.

Milner, P.S. \& Piasecki, S. 1996: Boreal Middle Jurassic dinoflagellate cyst stratigraphy of Jameson Land, East Greenland. In: Piasecki, S. et al. (eds): Formation of source and reservoir rocks in a sequence stratigraphic framework, Jameson Land, East Greenland. Energy research programme EFP-93, projects 1313/93-0010 and 0017. Danmarks og Grønlands Geologiske Undersøgelse Rapport 1996/30, Vol. I and II, 46 pp.

Piasecki, S. 1980: Middle to Late Jurassic dinoflagellate cyst stratigraphy from Milne Land (East Greenland) correlated with ammonite stratigraphy, 167 pp. Unpublished Ph.D. thesis, University of Copenhagen, Denmark.

Piasecki, S. 1994: Biostratigraphy of the Jurassic - Lower Cretaceous Ladegårdsåen Formation, Peary Land. In: Håkansson, E. (ed.): Wandel Sea Basin: Basin Analysis. EFP-91, Project No. 0012, 1-14.

Piasecki, S. 1996: Boreal dinoflagellate cyst stratigraphy of Middle to Upper Jurassic sediments of Milne Land, East Greenland. In: Piasecki, S. et al. (eds): Formation of source and reservoir rocks in a sequence stratigraphic framework, Jameson Land, East Greenland. Energy research programme EFP-93, Projects 1313/93-0010 and 0017. Danmarks og Grønlands Geologiske Undersøgelse Rapport 1996/30, Vol. I and II, $100 \mathrm{pp}$.

Piasecki, S. 2001: Three new Middle Jurassic dinoflagellate cysts of East Greenland. Neues Jahrbuch für Geologie und Paläontologie. Abhandlungen 219(1-2), 15-31.

Piasecki, S. \& Stemmerik, L. 2004: Jurassic dinoflagellate cysts from Hochstetter Forland, North-East Greenland. In: Stemmerik, L. \& Stouge, S. (eds): The Jurassic of North-East Greenland. Geological Survey of Denmark and Greenland Bulletin 5, 89-97 (this volume).

Piasecki, S., Stemmerik, L., Friderichsen, J.D. \& Higgins, A.K. 1994: Stratigraphy of the post-Caledonian sediments in the Germania Land area, North-East Greenland. Rapport Grønlands Geologiske Undersøgelse 162, 183-190.

Piasecki, S., Larsen, M., Therkelsen, J. \& Vosgerau, H. 2004: Jurassic dinoflagellate cyst stratigraphy of Hold with Hope, 
North-East Greenland. In: Stemmerik, L. \& Stouge, S. (eds): The Jurassic of North-East Greenland. Geological Survey of Denmark and Greenland Bulletin 5, 73-88 (this volume).

Ravn, J.P.J. 1911: On Jurassic and Cretaceous fossils from NorthEast Greenland. Meddelelser om Grønland 45(10), 437-500.

Smelror, M. 1993: Biogeography of Bathonian to Oxfordian (Jurassic) dinoflagellates: Arctic, NW Europe and circum-Mediterranean regions. Palaeogeography, Palaeoclimatology, Palaeoecology 102, 121-160.

Stemmerik, L. \& Piasecki, S. 1990: Post-Caledonian sediments in North-East Greenland between $76^{\circ}$ and $78^{\circ} 30^{\prime} \mathrm{N}$. Rapport Grønlands Geologiske Undersøgelse 148, 123-126.
Sykes, R.M. \& Callomon, J.H. 1979: The Amoeboceras zonation of the Boreal Upper Oxfordian. Palaeontology 22(4), 839903.

Sykes, R.M. \& Surlyk, F. 1976: A revised ammonite zonation of the Boreal Oxfordian and its application in North-East Greenland. Lethaia 9, 421-436.

Vosgerau, H., Larsen, M., Piasecki, S., Therkelsen, J. \& Surlyk, F. 2004: A new Middle-Upper Jurassic succession on Hold with Hope, North-East Greenland. In: Stemmerik, L. \& Stouge, S. (eds): The Jurassic of North-East Greenland. Geological Survey of Denmark and Greenland Bulletin 5, 51-71 (this volume). 